\title{
Impact of anthropogenic ocean acidification on thermal tolerance of the spider crab Hyas araneus
}

\author{
K. Walther, F. J. Sartoris, C. Bock, and H. O. Pörtner \\ Alfred-Wegener-Institute for Polar and Marine Research, Department Integrative Ecophysiology, Am Handelshafen 12, \\ 27570 Bremerhaven, Germany
}

Received: 16 February 2009 - Published in Biogeosciences Discuss.: 10 March 2009

Revised: 21 September 2009 - Accepted: 23 September 2009 - Published: 15 October 2009

\begin{abstract}
Future scenarios for the oceans project combined developments of $\mathrm{CO}_{2}$ accumulation and global warming and their impact on marine ecosystems. The synergistic impact of both factors was addressed by studying the effect of elevated $\mathrm{CO}_{2}$ concentrations on thermal tolerance of the coldeurythermal spider crab Hyas araneus from the population around Helgoland. Here ambient temperatures characterize the southernmost distribution limit of this species. Animals were exposed to present day normocapnia $(380 \mathrm{ppm}$ $\left.\mathrm{CO}_{2}\right), \mathrm{CO}_{2}$ levels expected towards $2100(710 \mathrm{ppm})$ and beyond $(3000 \mathrm{ppm})$. Heart rate and haemolymph $\mathrm{PO}_{2}\left(\mathrm{P}_{\mathrm{e}} \mathrm{O}_{2}\right)$ were measured during progressive short term cooling from 10 to $0^{\circ} \mathrm{C}$ and during warming from 10 to $25^{\circ} \mathrm{C}$. An increase of $\mathrm{P}_{\mathrm{e}} \mathrm{O}_{2}$ occurred during cooling, the highest values being reached at $0^{\circ} \mathrm{C}$ under all three $\mathrm{CO}_{2}$ levels. Heart rate increased during warming until a critical temperature $\left(T_{c}\right)$ was reached. The putative $T_{c}$ under normocapnia was presumably $>25^{\circ} \mathrm{C}$, from where it fell to $23.5^{\circ} \mathrm{C}$ under $710 \mathrm{ppm}$ and then $21.1^{\circ} \mathrm{C}$ under $3000 \mathrm{ppm}$. At the same time, thermal sensitivity, as seen in the $Q_{10}$ values of heart rate, rose with increasing $\mathrm{CO}_{2}$ concentration in the warmth. Our results suggest a narrowing of the thermal window of Hyas araneus under moderate increases in $\mathrm{CO}_{2}$ levels by exacerbation of the heat or cold induced oxygen and capacity limitation of thermal tolerance.
\end{abstract}

\section{Introduction}

The ongoing increase of $\mathrm{CO}_{2}$ in the atmosphere is a key driver of global warming (IPCC, 2001, 2007) and causes an inrease in accumulation of $\mathrm{CO}_{2}$ in the oceans leading to an acidification. Caldeira and Wickett (2005) modelled

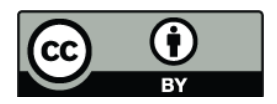

Correspondence to: $\mathrm{K}$. Walther (kathleen.walther@awi.de) different future scenarios for $\mathrm{CO}_{2}$ concentrations in the atmosphere and ocean. By 2100 they projected atmospheric and surface ocean levels of $710 \mathrm{ppm} \mathrm{CO}_{2}$ and for the year 2300 much beyond depending on the continued use of fossil fuel resources. Values reached may potentially comprise $3000 \mathrm{ppm} \mathrm{CO} 2 . \mathrm{CO}_{2}$ penetrates the surface ocean by air-tosea equilibration and is distributed by ocean circulation (Orr et al., 2001). In the studied area, the German Bight, North Sea, water depth is less than $100 \mathrm{~m}$ (Pohlmann, 1996). In this case, the whole water body will be equilibrated with $\mathrm{CO}_{2}$. The ongoing and predicted increase of $\mathrm{CO}_{2}$ levels leads to questions about the potential impact of ocean acidification on marine ecosystems in times of ocean warming (cf. Pörtner et al., 2005; Pörtner, 2008). Physiological mechanisms affected by $\mathrm{CO}_{2}$ have been identified, however, past studies on the influence of $\mathrm{CO}_{2}$ on crustaceans were conducted with a different focus and either used concentrations of about $10000 \mathrm{ppm}$ $\mathrm{CO}_{2}$ (Cameron, 1978, 1985; Wickins, 1984; Cameron and Iwama, 1987; Metzger et al., 2007; Pane and Barry, 2007) or rarely more realistic scenarios (e.g. about $800 \mathrm{ppm}$ used by Spicer et al., 2007). For reliable conclusions concerning the impact of $\mathrm{CO}_{2}$ on the physiology and fitness of crustaceans in the near future, it is necessary, however, to include realistic $\mathrm{CO}_{2}$ concentrations in those studies, as postulated for $2100(710 \mathrm{ppm})$ or beyond (3000 ppm), and combine them with changing temperatures.

The present study investigates the impacts of $\mathrm{CO}_{2}$ and temperature on the physiology of Hyas araneus in the context of the thermal tolerance concept originally developed in crustaceans, namely by Frederich and Pörtner (2000) for Maja squinado. The thermal tolerance window as characterized by temperature dependent haemolymph oxygen partial pressure $\left(\mathrm{P}_{\mathrm{e}} \mathrm{O}_{2}\right)$, heart and ventilation rates comprises the temperature range of aerobic performance (or scope). The thermal optimum is the temperature where performance is maximal, supported by high haemolymph oxygen tension, and maximum scope (i.e. increase above maintenance) for heart

Published by Copernicus Publications on behalf of the European Geosciences Union. 
and ventilation rates. The earliest limits of the thermal tolerance range with ecological relevance (Pörtner and Knust, 2007) are reflected by high and low pejus temperatures $\left(T_{p}\right)$. Warming leads to rising oxygen demand that can initially be met by oxygen supply through enhanced ventilation and heart rate (Zainal et al., 1992; Frederich and Pörtner, 2000). The upper $T_{p}$ indicates the point, where ventilation and heart rates level off and remain constant indicating capacity limitation. Haemolymph oxygen partial pressure decreases within the subsequent pejus range, as a result of a mismatch developing between the rising oxygen demand for maintenance and the limited capacities of ventilation and circulation in oxygen supply. Beyond pejus range, a critical temperature defines the onset of anaerobic metabolism, where accumulation of L-lactate, succinate and inorganic phosphate sets in and aerobic scope vanishes (Frederich and Pörtner, 2000; Melzner et al., 2006). In the following pessimum range animal life is sustained for limited time only. Such critical temperatures can also be identified from patterns of $\mathrm{P}_{e} \mathrm{O}_{2}$ or heart rate. A drop in heart rate characterizes the critical temperature as it coincides with the onset for anaerobic metabolite accumulation (Frederich and Pörtner, 2000; Melzner et al., 2006). As $\mathrm{P}_{\mathrm{e}} \mathrm{O}_{2}$ levels depend on oxygen consumption and are controlled by ventilation and heart rate the determination of critical thermal maxima in different crab species from heart rate measurements (Ahsanullah and Newell, 1971; Cuculescu et al., 1998; Stillman and Somero, 1996; Worden et al., 2006) would likely match critical thermal limits according to the concept of oxygen and capacity limited thermal tolerance.

The impact of moderate elevations in $\mathrm{CO}_{2}$ on thermal window may be small in the thermal optimum but may exert stronger effects on thermal limits as hypothesized earlier (Pörtner et al., 2005; Pörtner and Farrell, 2008). At thermal extremes it may exacerbate the reduction in aerobic scope towards thermal extremes (cf. Metzger et al., 2007) which will decrease functional capacity and fitness and may minimize survival in the field once animals (Pörtner and Knust, 2007).

Little is known about the effect of $\mathrm{CO}_{2}$ on temperature tolerance of cold-eurythermal invertebrates, especially in species at the border of their temperature dependent distribution range along a latitudinal gradient. The spider crab Hyas araneus (L.) was chosen as a model for a cold temperate crustacean. Hyas araneus is found in the North Atlantic from the North Sea, near Helgoland, Germany, to the Arctic around Svalbard, Norway (Christiansen, 1969). During the year the mean ambient temperature of the North Sea varies between $3^{\circ} \mathrm{C}$ and $18^{\circ} \mathrm{C}$ and reaches maxima of about $20^{\circ} \mathrm{C}$ in summer (Wiltshire and Manly, 2004). In Svalbard waters Hyas araneus is exposed to temperatures between $0^{\circ} \mathrm{C}$ and $6^{\circ} \mathrm{C}$ (Svendsen et al., 2002). The species lives on stony, sandy and soft bottom from $<1$ down to $360 \mathrm{~m}$, most commonly at depths less than $50 \mathrm{~m}$. Males may reach a carapace length up to $105 \mathrm{~mm}$ (Christiansen, 1969).
The present study investigates the thermal window of the Hyas araneus population around Helgoland in the context of the large temperature fluctuations experienced by the species in the North Sea. One further question addressed in this study is to what extent $\mathrm{CO}_{2}$ affects the wide thermal tolerance range and whether this effect sets in under expected $\mathrm{CO}_{2}$ accumulation scenarios in both atmosphere and surface waters.

\section{Materials and methods}

\subsection{Animals}

Adult Hyas araneus (L.), including males and females with similar sizes (carapace length: $68.8 \pm 2.8 \mathrm{~mm}$ ) were caught between August and October 2007 around Helgoland, Germany. The females used were all in the same reproductive stage and were not carrying egg masses. The animals were held in tanks with aerated re-circulating natural seawater at $10 \pm 0.2^{\circ} \mathrm{C}, 32-33 \%$ salinity, $\mathrm{pH} 8.0$ and a $12 \mathrm{~h}$ light cycle at the Alfred-Wegener-Institute in Bremerhaven, Germany, for at least 4 weeks before the beginning of the experiments. The animals were fed twice a week with pieces of mussels (Mytilus edulis). A thermostat (Lauda, T1200) ensured tight temperature control in the experimental setup tank. The temperature ramp starting from a control temperature of $10^{\circ} \mathrm{C}$ was coded using the wintherm plus program (Version 2.2) of the thermostat. The water was cooled from $10^{\circ} \mathrm{C}$ to $0^{\circ} \mathrm{C}$ and warmed continuously from $10^{\circ} \mathrm{C}$ to $25^{\circ} \mathrm{C}$ at a rate of $1^{\circ} \mathrm{C}$ per $\mathrm{h}$. The accuracy of the temperature ramp was $1 \pm 0.2^{\circ} \mathrm{C} / \mathrm{h}$ for cooling and $1 \pm 0.1^{\circ} \mathrm{C} / \mathrm{h}$ for warming protocols.

\subsection{Surgical procedures}

Prior to experimentation animals were prepared for continuous simultaneous measurements of arterial haemolymph oxygen partial pressure $\left(\mathrm{P}_{\mathrm{e}} \mathrm{O}_{2}\right)$ and of heart rate. Briefly, two holes were drilled through the carapace, one directly over the heart, avoiding injury to the hypodermis. This hole was covered with latex dam to prevent haemolymph loss. The sleeve of an inflexible venipuncture needle (after Strauss, BRAUN, Germany) was used as an adapter for fixation of the oxygen optode. This adapter was fixed with dental wax over the drilled hole. A second hole was drilled behind the optode preparation for fixation of the Doppler probe used for heart rate measurements.

\subsection{Oxygen measurements}

Measurements of arterial $\mathrm{P}_{\mathrm{e}} \mathrm{O}_{2}$ were carried out with microoptodes (NTH-PSt1-L5ITF-PC3,1-NS 35x1,20-YOP, PreSens GmbH, 93053 Regensburg, Germany). Data were recorded on-line by use of temperature compensation via TX2-A oxygen monitors and software (Oxy View TX2 C 
4.02) (PreSens Regensburg, Germany). Optodes were calibrated in air-saturated millipore water $(100 \%)$ and in oxygenfree seawater, using sodium disulfide $(0 \%)$. Haemolymph clotting around the oxygen probes was prevented by rinsing the probes in a heparin solution $(5000 \mathrm{U} / \mathrm{ml})$ prior to use. The tip of the optode was inserted through the adapter and latex dam into the pericardial sinus and fixed with parafilm. Oxygen values were recorded as $\%$ air saturation and converted to $\mathrm{P}_{\mathrm{e}} \mathrm{O}_{2}$.

\subsection{Heart rate measurements}

Measurements of heart rate were carried out with a noninvasive laser Doppler perfusion monitor (LDPM PeriFlux System 5000, Perimed AB, Järfälla, Sweden) as described by Lannig et al. (2008). Prior to the experiments, the probe was two-point calibrated. The laser Doppler signal was monitored by chart 5 (AD instruments). Heart rates (beats/min) were derived from regular changes in the laser Doppler signal caused by fluctuating haemolymph flow. Laser Doppler values were averaged for individual temperature steps $\left(0.1^{\circ} \mathrm{C}\right.$ for the warming ramp, $0.2^{\circ} \mathrm{C}$ for the cooling ramp).

\section{$2.5 \mathrm{CO}_{2}$ incubations}

After the implantation of the sensors, animals were allowed to recover for $24 \mathrm{~h}$ in $75-1$ seawater tanks at $10^{\circ} \mathrm{C}$. During the experiments animals were exposed to different $\mathrm{CO}_{2}$ concentrations (normocapnia, $710 \mathrm{ppm}, 3000 \mathrm{ppm}$ ) in the seawater. For normocapnic conditions $\left(380 \mathrm{ppm} \mathrm{CO} \mathrm{CO}_{2}\right.$ ) seawater was bubbled with air. For exposure to different $\mathrm{CO}_{2}$ concentrations Wösthoff gas mixing pumps (Typ 2M303/a-F-T, 5kM303/a-F, 5kM402-F) were used to mix $\mathrm{CO}_{2}$-free air with $\mathrm{CO}_{2}$. During exposure to $3000 \mathrm{ppm} \mathrm{CO}_{2}$ water, water $\mathrm{pH}$ dropped from 8.0 to 7.3 (expected $\mathrm{pH}$ value calculated as 7.29). Equilibration with $710 \mathrm{ppm} \mathrm{CO} \mathrm{CO}_{2}$ concentration caused a pH decrease from 8.0 to 7.8 (expected value calculated as $\mathrm{pH}$ 7.80). Prior to exposure to the temperature ramp animals were exposed for $24 \mathrm{~h}$ to $10^{\circ} \mathrm{C}$ at each particular $\mathrm{CO}_{2}$ concentration. New acid-base equilibria were reached in body fluids of the crabs within $24 \mathrm{~h}$ (Truchot, 1984). All animals survived experimentation.

\subsection{Data analysis}

Data are presented as means \pm SE. Statistical significance was tested using one-way ANOVA and post hoc Tukey tests (GraphPad Software, Prism 4). Discontinuities in the slopes of heart rate changes vs. temperature were calculated from intersections of fitted two-phase regressions according to the minimum sum of squares and were presented as breakpoints and critical temperatures $\left(T_{c}\right)$. Linear regression lines were calculated with Prism 4 (GraphPad Software). Nonlinear regression curves were fitted using Boltzmann sigmoidal equation at Prism 4 (GraphPad Software). $Q_{10}$ values were calculated from the exponential phases of
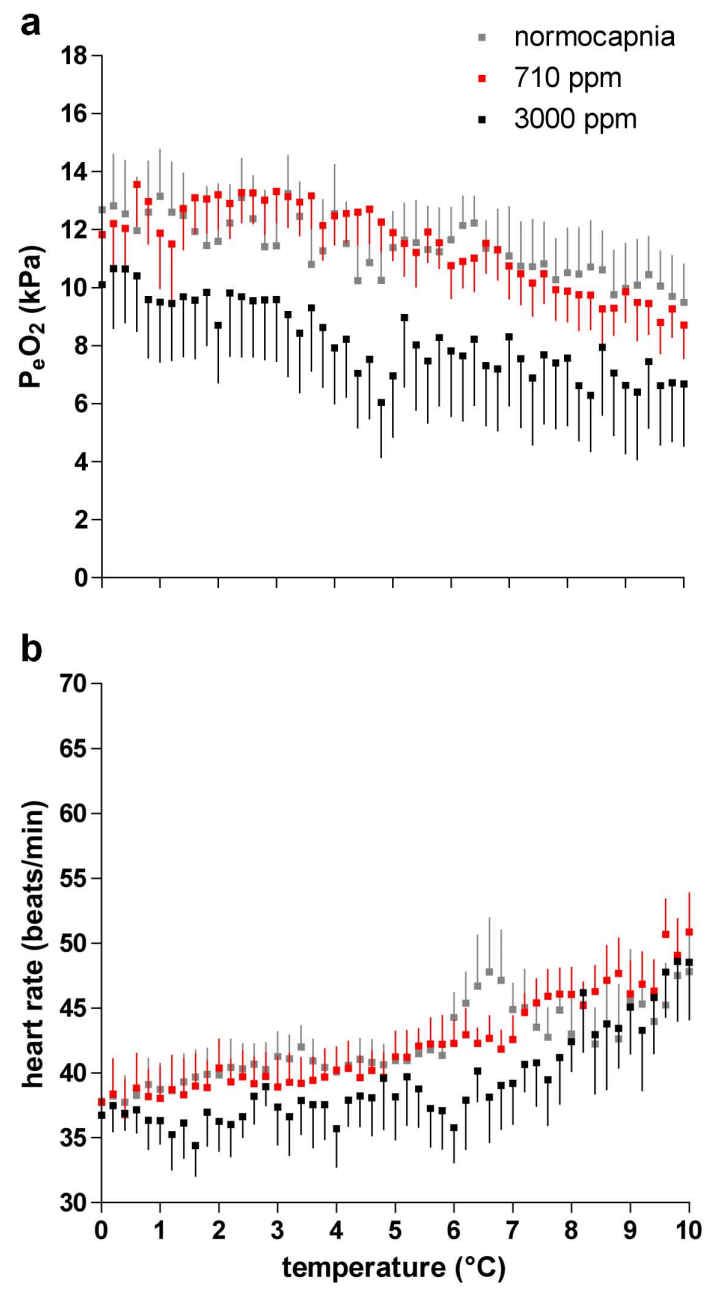

Fig. 1. Temperature dependent patterns of $\mathrm{P}_{\mathrm{e}} \mathrm{O}_{2}$ and heart rate of Hyas araneus exposed to different $\mathrm{CO}_{2}$ concentrations during acute cooling from 10 to $0^{\circ} \mathrm{C}$ (grey: normocapnia; red: $710 \mathrm{ppm}$; black: $3000 \mathrm{ppm}$ ). (a). $\mathrm{P}_{\mathrm{e}} \mathrm{O}_{2}$, values under $3000 \mathrm{ppm}$ were significantly different from those under normocapnia and $710 \mathrm{ppm}$ (ANOVA, $p<0.001$ ). (b). Heart rate under $3000 \mathrm{ppm}$ was significantly different from those under normocapnia and $710 \mathrm{ppm}$ (ANOVA, $p<0.001$ ). Data are means $\pm \mathrm{SE}, n=7$ (normocapnia) and 8 (710 ppm, $3000 \mathrm{ppm})$, respectively.

heart rate increments, after De Wachter and Wilkens (1996): $Q_{10}=\left(f_{H 2} / f_{H 1}\right) \exp \left[10 /\left(t_{2}-t_{1}\right)\right]$ with $t=$ temperature and $f_{H}$ $=$ heart rate.

\section{Results}

Acute cooling from $10^{\circ} \mathrm{C}$ to $0^{\circ} \mathrm{C}$ resulted in a slight increase of arterial $\mathrm{P}_{\mathrm{e}} \mathrm{O}_{2}$ under all three conditions, i.e. normocapnia, $710 \mathrm{ppm}$, as well as $3000 \mathrm{ppm} \mathrm{CO}_{2}$, starting from values of $\mathrm{P}_{\mathrm{e}} \mathrm{O}_{2}$ which fell with rising $\mathrm{CO}_{2}$ levels (Fig. 1a). Under normocapnia mean $\mathrm{P}_{\mathrm{e}} \mathrm{O}_{2}$ ranged from $9.49 \mathrm{kPa}$ at $10^{\circ} \mathrm{C}$ to $13.24 \mathrm{kPa}$ at $0^{\circ} \mathrm{C}$, under $710 \mathrm{ppm}$ values ranged from 
a
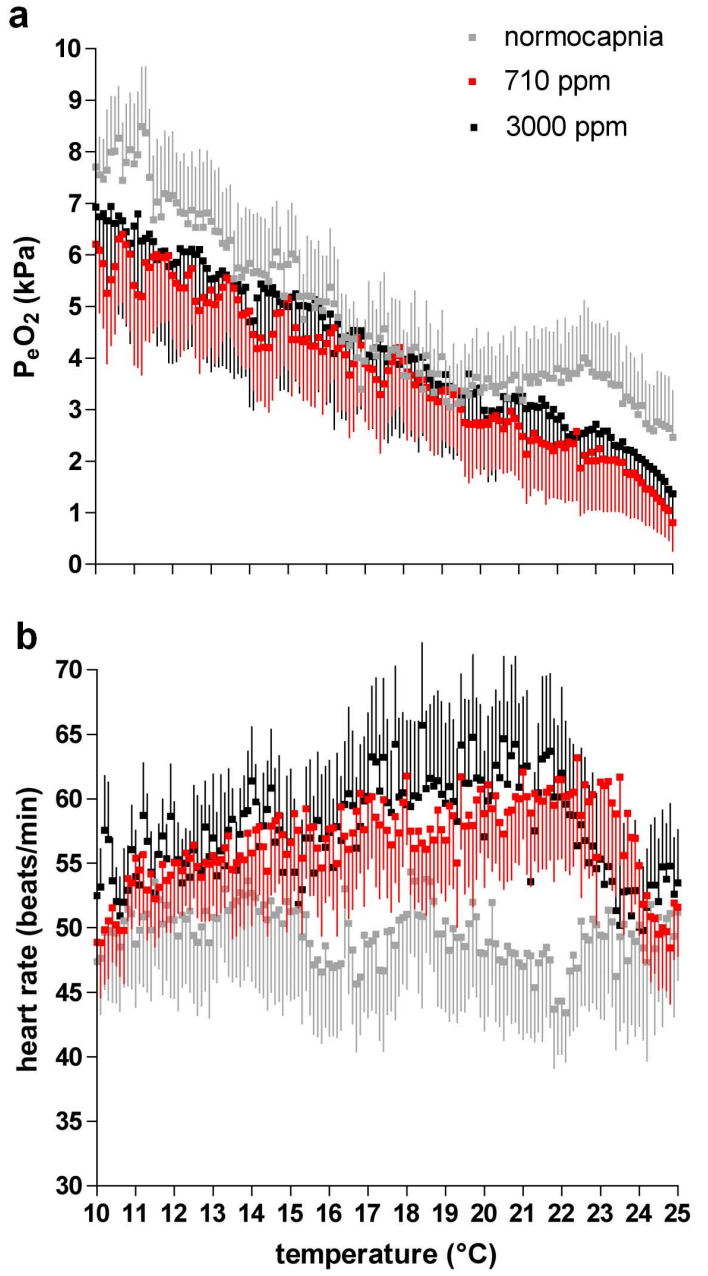

Fig. 2. Temperature dependent patterns of $\mathrm{P}_{\mathrm{e}} \mathrm{O}_{2}$ and heart rate of Hyas araneus exposed to different $\mathrm{CO}_{2}$ concentrations during acute warming from 10 to $25^{\circ} \mathrm{C}$ (grey: normocapnia; red: $710 \mathrm{ppm}$; black: $3000 \mathrm{ppm}$ ). (a). $\mathrm{P}_{\mathrm{e}} \mathrm{O}_{2}$ values were significantly different between values under $3000 \mathrm{ppm}$ and those under normocapnia and $710 \mathrm{ppm}$ (ANOVA, $p<0.01$ ) and between values under normocapnia and $710 \mathrm{ppm}$ (ANOVA, $p<0.01$ ). (b). Heart rate under normocapnia was significantly different from those under $710 \mathrm{ppm}$ and $3000 \mathrm{ppm}$ (ANOVA, $p<0.001$ ). Data are means $\pm \mathrm{SE}, n=7$ (normocapnia) and 8 (710 ppm, $3000 \mathrm{ppm})$.

$8.72 \mathrm{kPa}$ to $13.56 \mathrm{kPa}$ and, under $3000 \mathrm{ppm}$, from $6.05 \mathrm{kPa}$ to $10.65 \mathrm{kPa}$. The $\mathrm{P}_{\mathrm{e}} \mathrm{O}_{2}$ values of crabs incubated under $3000 \mathrm{ppm}$ were significantly lower than in animals under both normocapnia and $710 \mathrm{ppm}$ (ANOVA, $p<0.001$ ).

Heart rate decreased between $10^{\circ} \mathrm{C}$ and $6^{\circ} \mathrm{C}$ with different slopes depending on $\mathrm{CO}_{2}$ concentration (Fig. 1b). The heart rate of crabs incubated under $3000 \mathrm{ppm} \mathrm{CO}_{2}$ fell more strongly than in animals incubated under $710 \mathrm{ppm}$ and normocapnia. The statistical comparison of the three data sets obtained between $10^{\circ} \mathrm{C}$ and $0^{\circ} \mathrm{C}$ revealed a significant difference between animals under normocapnia and $3000 \mathrm{ppm}$ as well as between those under $710 \mathrm{ppm}$ and $3000 \mathrm{ppm}$
(ANOVA, $p<0.001$ ). Hyas araneus specimens incubated under $3000 \mathrm{ppm}$ displayed a lower heart rate than those under $710 \mathrm{ppm}$ or normocapnia. Heart rate remained more or less constant between 6 and $0^{\circ} \mathrm{C}$ under all conditions, at a rate of $37.2 \pm 1.2$ beats $/ \mathrm{min}$ under $3000 \mathrm{ppm}, 39.64 \pm 1.4$ beats $/ \mathrm{min}$ under $710 \mathrm{ppm}$ and $40.27 \pm 1.4$ beats/min under normocapnia.

Upon acute warming from $10^{\circ} \mathrm{C}$ to $25^{\circ} \mathrm{C}$ haemolymph $\mathrm{P}_{\mathrm{e}} \mathrm{O}_{2}$ values of Hyas araneus decreased (Fig. 2a), from a maximum of about $8.5 \mathrm{kPa}$ at $10^{\circ} \mathrm{C}$ under normocapnia to a minimum of about $2.5 \mathrm{kPa}$ at $25^{\circ} \mathrm{C}$. Under the same warming protocol mean $\mathrm{P}_{\mathrm{e}} \mathrm{O}_{2}$ in crabs under $710 \mathrm{ppm}$ fell from $6.3 \mathrm{kPa}$ to $0.8 \mathrm{kPa}$, and in specimens under $3000 \mathrm{ppm}$ from $6.9 \mathrm{kPa}$ to $1.37 \mathrm{kPa}$. Differences were statistically significant between data obtained under normocapnia and $710 \mathrm{ppm}$ (ANOVA, $p<0.001$ ) as well as between those under $3000 \mathrm{ppm}$ and normocapnia or $710 \mathrm{ppm}$ (ANOVA, $p<0.01$ ).

Depending on $\mathrm{CO}_{2}$ treatment heart rate of Hyas araneus displayed different patterns upon acute warming between $10^{\circ} \mathrm{C}$ and $25^{\circ} \mathrm{C}$ (Fig. 2b). Lowest rates were seen under normocapnia with relatively stable mean values between 43.7 and 55.0 beats $/ \mathrm{min}$. In contrast, heart rate increased under $710 \mathrm{ppm}$ from 48.9 beats $/ \mathrm{min}$ at $10^{\circ} \mathrm{C}$ to a maximum of 63.17 beats $/ \mathrm{min}$ at $22.4^{\circ} \mathrm{C}$ leveling off towards 61.67 beats $/ \mathrm{min}$ at $23.5^{\circ} \mathrm{C}$ and decreasing rapidly thereafter to 48.44 beats $/ \mathrm{min}$ at $24.8^{\circ} \mathrm{C}$. Crabs under $3000 \mathrm{ppm}$ displayed an increase in heart rate from 52.49 beats $/ \mathrm{min}$ at $10^{\circ} \mathrm{C}$ to 65.6 beats $/ \mathrm{min}$ at $18.4^{\circ} \mathrm{C}$ leveling off to 62.52 beats $/ \mathrm{min}$ at $21.1^{\circ} \mathrm{C}$ and decreasing thereafter to 50.05 beats $/ \mathrm{min}$ at $24^{\circ} \mathrm{C}$. Data under $3000 \mathrm{ppm}$ were significantly different from those obtained under normocapnia or $710 \mathrm{ppm}$ (ANOVA, $p<0.001$ ).

Figure 3 presents a comparison of $\mathrm{P}_{\mathrm{e}} \mathrm{O}_{2}$ values and heart rates within the whole temperature range of all three incubations (normocapnia (Fig. 3a), 710 ppm (Fig. 3b) and 3000 ppm (Fig. 3c)). Contrasting trends result for $\mathrm{P}_{\mathrm{e}} \mathrm{O}_{2}$ and heart rate. Clear changes in the development of heart rate upon warming under $710 \mathrm{ppm}$ and $3000 \mathrm{ppm}$ define the critical temperatures $\left(T_{c}\right)$ from calculated breakpoints. The upper $T_{c}$ under $710 \mathrm{ppm}$ was $23.5^{\circ} \mathrm{C}$ and under $3000 \mathrm{ppm} 21.1^{\circ} \mathrm{C}$. Under normocapnic conditions no breakpoint could be identified in the observed temperature range between 10 and $25^{\circ} \mathrm{C}$, confirming that the $T_{c}$ is found beyond $25^{\circ} \mathrm{C}$ under normocapnia $\left(T_{c}>25^{\circ} \mathrm{C}\right)$.

Accordingly, $Q_{10}$ values of Hyas araneus heart rates (calculated from the exponential phases of heart rate increments between 6 and $12^{\circ} \mathrm{C}$ ) increased from 1.25 , (heart rate increment: 44.26 beats $/ \mathrm{min}$ to 50.60 beats $/ \mathrm{min}$ ) under normocapnia to 1.55 (42.27 to 55.06 beats $/ \mathrm{min}$ ) under $710 \mathrm{ppm} \mathrm{CO}_{2}$ and 2.05 (heart rate increment: 35.79 to 55.08 beats $/ \mathrm{min}$ ) under $3000 \mathrm{ppm} \mathrm{CO}_{2}$, (Fig. 4). These data demonstrate an incremental response to temperature with increasing $\mathrm{CO}_{2}$ levels. 

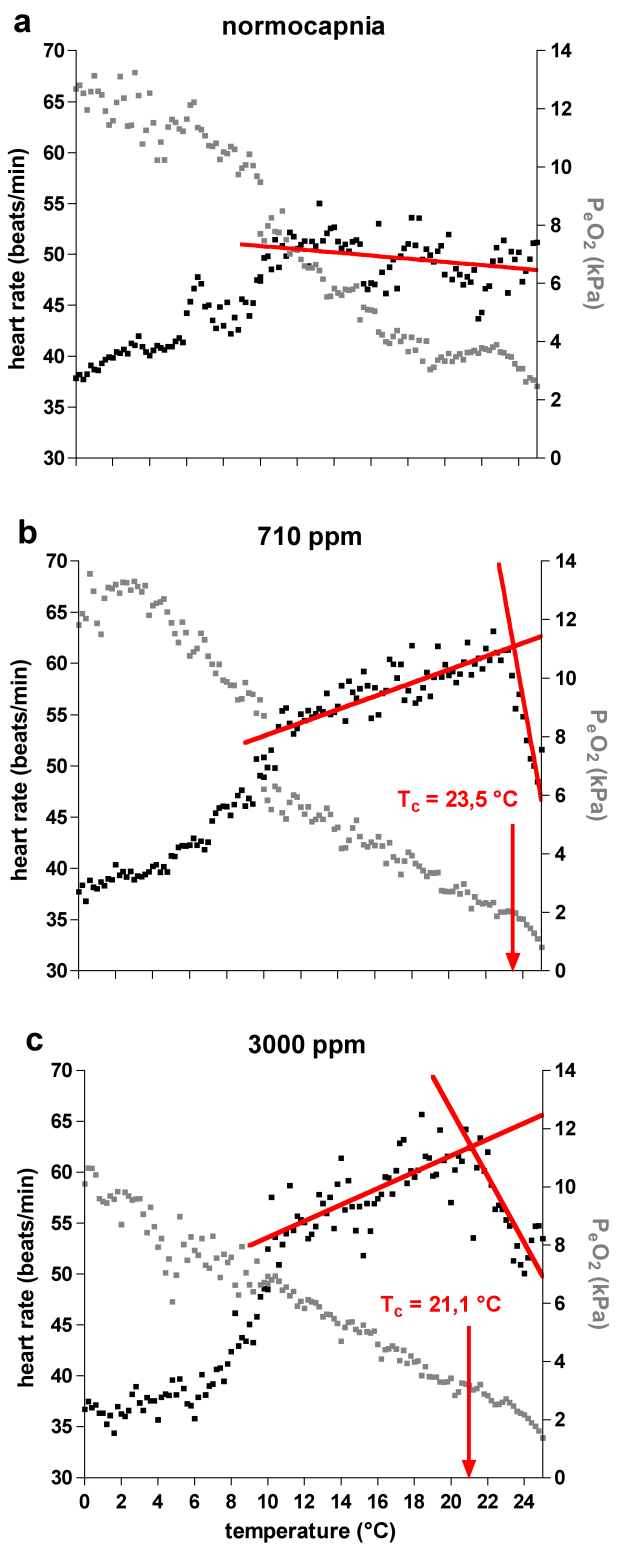

Fig. 3. Combined depiction of $\mathrm{P}_{\mathrm{e}} \mathrm{O}_{2}$ (black) and heart rate (grey) data (means) of Hyas araneus between 0 and $25^{\circ} \mathrm{C}$ (starting point $10^{\circ} \mathrm{C}$ ). (a) normocapnia. (b) $710 \mathrm{ppm}$. (c) $3000 \mathrm{ppm}$. The red line indicates the shift in the upper $T_{c}$ with rising $\mathrm{CO}_{2}$ levels ( $n=7$, normocapnia, $n=8,710 \mathrm{ppm}$ and $3000 \mathrm{ppm}$ ). Discontinuities in the temperature dependence of heart rate data (means) between 10 and $25^{\circ} \mathrm{C}$ under normocapnia, $710 \mathrm{ppm} \mathrm{CO}_{2}$ and $3000 \mathrm{ppm} \mathrm{CO}_{2}$, analysed from linear regressions intersecting at the respective breakpoints, defined as critical temperatures $\left(T_{C}\right)$. Data under normocapnia revealed no breakpoint in the tested temperature range. Under $710 \mathrm{ppm}$, the $T_{C}$ was $23.5^{\circ} \mathrm{C}$, under $3000 \mathrm{ppm}$, the $T_{C}$ was $21.1^{\circ} \mathrm{C}$. Regressions under $710 \mathrm{ppm}$ are: $f\left(10-23.5^{\circ} \mathrm{C}\right)=46.44+(0.6482 \pm 0.01816) \bullet \mathrm{x}, \quad p<0.0001, \quad f(23.5-$ $\left.25^{\circ} \mathrm{C}\right)=296.8+(-10 \pm 0.7759) \bullet x, \quad p<0.0001 . \quad$ Regressions under $3000 \mathrm{ppm}$ are: $f\left(10-21.1^{\circ} \mathrm{C}\right)=45.59+(0.8025 \pm 0.031) \bullet \mathrm{x}$, $p<0.0001, f\left(21.1-25^{\circ} \mathrm{C}\right)=131.5+(-3.27 \pm 0.1852) \bullet \mathrm{x}, p<0.0001$.

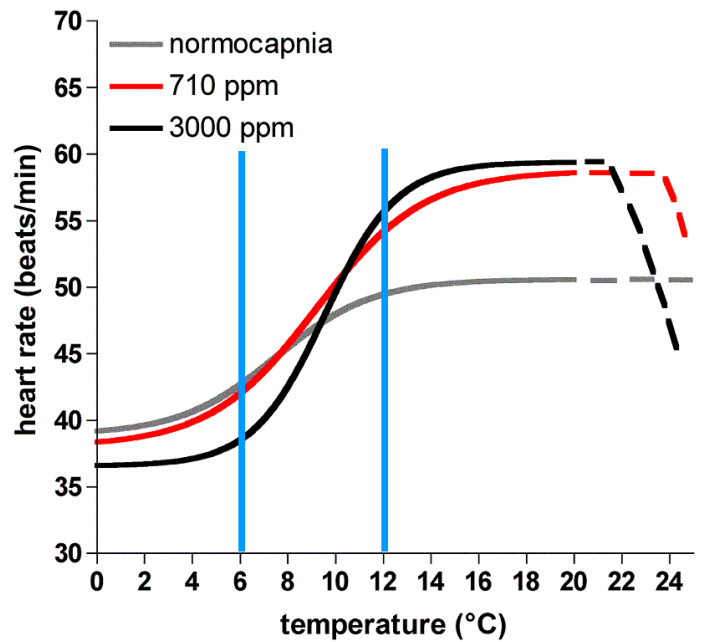

Fig. 4. Schematic model of heart rate in Hyas araneus under normocapnia (grey), $710 \mathrm{ppm}$ (red) and $3000 \mathrm{ppm}$ (black) $\mathrm{CO}_{2}$ at temperatures between 0 and $25^{\circ} \mathrm{C}$. Note the shift in thermal responses of heart rate, reflected in $Q_{10}$ values, calculated from the exponential phases between 6 and $12^{\circ} \mathrm{C}$ (blue bars). $Q_{10}$ values were larger under $3000 \mathrm{ppm}\left(Q_{10}=2.05\right)$ than under $710 \mathrm{ppm}$ $\left(Q_{10}=1.55\right)$ or normocapnia $\left(Q_{10}=1.25\right)$. As a result, onset of a drop in heart rate and upper critical temperature were seen at lower temperatures under 3000 than under $710 \mathrm{ppm}$. Heart rate under normocapnia showed no warming induced decrement. Non-linear regression fit with Boltzmann sigmoidal equation for normocapnia: $\mathrm{y}=38.92+(50.60-38.92) /(1+\exp ((7.502-\mathrm{x}) / 2.014)) ; r^{2}=0.8429$, for $710 \mathrm{ppm}: \quad \mathrm{y}=38.04+(58.76-38.04) /(1+\exp ((9.201-\mathrm{x}) / 2.235))$; $r^{2}=0.9757$, for $3000 \mathrm{ppm}: \mathrm{y}=36.57+(59.40-36.57) /(1+\exp ((9.566-$ $\mathrm{x}) / 1.506)) ; r^{2}=0.9531$.

\section{Discussion}

\subsection{Thermal tolerance window of Hyas araneus}

The aim of the present study was to illustrate the impact of anthropogenic $\mathrm{CO}_{2}$ accumulation in the oceans on the thermal tolerance window of the spider crab (Hyas araneus) population from Helgoland. For an examination of the thermal tolerance window haemolymph oxygen partial pressure $\left(\mathrm{P}_{\mathrm{e}} \mathrm{O}_{2}\right)$ and heart rate were measured during warming and cooling protocols.

Hyas araneus exposed to the cooling protocol from $10^{\circ} \mathrm{C}$ to $0^{\circ} \mathrm{C}$ (Fig. 1a) displayed a moderate increase in arterial haemolymph oxygen partial pressure while heart rate decreased. Specimens exposed to warming from $10^{\circ} \mathrm{C}$ to $25^{\circ} \mathrm{C}$ (Fig. 2a) experienced a decrease in mean $\mathrm{P}_{\mathrm{e}} \mathrm{O}_{2}$ value while heart rate rose under normocapnic conditions. The comprehensive depiction in Fig. 3 shows that arterial haemolymph $\mathrm{P}_{\mathrm{e}} \mathrm{O}_{2}$ continued to rise down to $0^{\circ} \mathrm{C}$. These data contrast the first such data set elaborated in the spider crab Maja squinado (Frederich and Pörtner, 2000) where the temperature dependent pattern of arterial $\mathrm{P}_{\mathrm{e}} \mathrm{O}_{2}$ characterized the thermal tolerance window. In Maja squinado $\mathrm{P}_{\mathrm{e}} \mathrm{O}_{2}$ fell upon cooling 
until a lower critical temperature was reached, subsequently anaerobic metabolism set in and indicated cold induced oxygen deficiency (Frederich and Pörtner, 2000).

The optimum temperature range of Maja squinado was seen between low and high pejus temperatures of 8.9 and $17.8^{\circ} \mathrm{C}$, respectively (Frederich and Pörtner, 2000), with a maximum arterial $\mathrm{P}_{\mathrm{e}} \mathrm{O}_{2}$ of $92.6 \mathrm{mmHg}$, equivalent to $12.3 \mathrm{kPa}$, which was more or less stable between those socalled pejus thresholds. The highest $\mathrm{P}_{\mathrm{e}} \mathrm{O}_{2}$ value recorded in Hyas araneus was $13.6 \mathrm{kPa}$ at the coldest temperature of $0^{\circ} \mathrm{C}$. These data indicate that the optimum performance range of Hyas araneus is shifted to colder temperatures when compared to Maja squinado. As Hyas araneus reached their highest arterial $\mathrm{P}_{\mathrm{e}} \mathrm{O}_{2}$ values in the cold this may indicate that the species experiences no oxygen limitation at extremely cold temperatures, at least in its central organs close to the heart. However, recent data indicate that venous oxygen tensions may more closely reflect thermal limitation (F. Giomi, personal communication). Limitation in the perfusion of peripheral organs associated with low venous oxygen tensions or in general, in functional capacity upon further cooling, may thus occur in similar ways as shown in Maja squinado (Bock et al., 2001). Due to capacity limitation in neuromuscular systems all reptant decapod crustaceans were hypothesized to be excluded from permanently low temperatures of $-1^{\circ} \mathrm{C}$ in polar oceans (Frederich et al., 2000).

The range of thermal tolerance of Hyas araneus is mirrored in its range of natural distribution from the North Sea around Helgoland, Germany, northward to the Arctic around Svalbard, Norway (Christiansen, 1969). Hyas araneus can thus be characterized as a cold-eurythermal species with a lower thermal optimum range than seen in the warmeurythermal Maja squinado (Frederich and Pörtner, 2000). Mean ambient water temperature of the North Sea at Helgoland Roads is about $3^{\circ} \mathrm{C}$ in winter and reaches $18^{\circ} \mathrm{C}$, maximally $20^{\circ} \mathrm{C}$, in summer (Wiltshire and Manly, 2004). Temperatures in Svalbard waters fluctuate between 0 and $6^{\circ} \mathrm{C}$ (Svendsen et al., 2002). This wide range of habitat temperatures implies a wide thermal tolerance range of this spider crab.

The heart rate of Hyas araneus decreased exponentially between $10^{\circ} \mathrm{C}$ and $0^{\circ} \mathrm{C}$ under normocapnic conditions (Fig. 1b). Heart rate reached 37.2 beats $/ \mathrm{min}$ at $0^{\circ} \mathrm{C}$. This value appears high compared to the 20 beats/min reported for Hyas araneus at $0^{\circ} \mathrm{C}$ (Frederich et al., 2000). In Maja squinado, heart rate at $0^{\circ} \mathrm{C}$, below the lower critical temperature and within the pessimum range was 10 beats $/ \mathrm{min}$. A lower heart beat rate might not only reflect thermal limitation but also relate to the somewhat larger body size of M. squinado (carapace length: $142.5 \pm 30.5 \mathrm{~mm}$ (Bernárdez et al., 2005) compared to carapace length: $68.8 \pm 2.8 \mathrm{~mm}$ in H. araneus) (Ahsanullah and Newell, 1971; DeFur and Mangum, 1979). Maja squinado's heart rates in the optimum range $\left(9.3^{\circ} \mathrm{C}\right.$ to $\left.17.3^{\circ} \mathrm{C}\right)$ were about 40 to 60 beats $/ \mathrm{min}$ (Frederich and Pörtner, 2000), at the low end of rates seen in $\mathrm{H}$. araneus at $10^{\circ} \mathrm{C}$ and beyond. Close to $0^{\circ} \mathrm{C}$, high $\mathrm{P}_{\mathrm{e}} \mathrm{O}_{2}$ values combined with relatively high heart rates of Hyas araneus reflect maintenance of performance at cold temperatures. The rise in arterial $\mathrm{P}_{\mathrm{e}} \mathrm{O}_{2}$ in the cold reflects the facilitation in oxygen supply in cold waters, once tissue functional capacities are cold adapted. This facilitation is due to rising oxygen solubility in the cold in water and body fluids combined with a putative cold induced reduction of metabolic rates (cf. Pörtner, 2002). This conclusion is supported by the relaxed oxygen supply situation and the respective molecular to systemic adaptations of polar stenotherms (cf. Pörtner, 2006).

Under normocapnia and both elevated $\mathrm{CO}_{2}$ tensions tested Hyas araneus heart rate decreased from 10 to $6^{\circ} \mathrm{C}$ and was nearly constant between 6 and $0^{\circ} \mathrm{C}$, reflecting the lower end of an exponential decline phase which characterizes the lower end of the thermal window. This pattern is similar to the pattern of oxygen consumption within thermal tolerance windows as seen in the squat lobster Munida rugosa (Zainal et al., 1992) and in other marine invertebrates, e.g. the lugworm, Arenicola marina (Wittmann et al., 2008). Upon warming from 10 to $25^{\circ} \mathrm{C}$ the heart rate of Hyas araneus remained more or less constant under normocapnic conditions (Fig. 2b). The exponential phase of the heart rate was seen between 6 and $12^{\circ} \mathrm{C}$ under all $\mathrm{CO}_{2}$ conditions. The upper point of change between exponential and linear phase is defined as the upper pejus temperature, where the circulatory performance of $H$. araneus from the Helgoland population reaches its upper capacity limit. At higher temperatures than $T_{p}$ the analysis revealed no further discontinuities in the normocapnic data (Fig. 3). For comparison, heart rate data of Maja squinado displayed a break at $31.5^{\circ} \mathrm{C}$, close to their critical temperature identified by the onset of anaerobic metabolism (Frederich and Pörtner, 2000). We conclude that the upper critical temperature of the Hyas araneus from the population at Helgoland under normocapnia is likely reached above $25^{\circ} \mathrm{C}$.

The observations that the maximal $\mathrm{P}_{\mathrm{e}} \mathrm{O}_{2}$ of Hyas araneus is found close to $0^{\circ} \mathrm{C}$, that the upper pejus temperature is likely seen around $10^{\circ} \mathrm{C}$ to $12^{\circ} \mathrm{C}$ and that the critical temperature of Hyas araneus is found above $25^{\circ} \mathrm{C}$ indicate that the width of the pejus range starting beyond $10^{\circ} \mathrm{C}$ to $12^{\circ} \mathrm{C}$ is similar or somewhat broader than that of Maja squinado which displays a pejus range between 17.3 and $31.1^{\circ} \mathrm{C}$ (Frederich and Pörtner, 2000). This and the progressive rise in $\mathrm{P}_{\mathrm{e}} \mathrm{O}_{2}$ within the optimum range towards the more extreme cold distinguishes Hyas araneus as a cold-eurythermal species from the warm-eurythermal Maja squinado.

\section{2 $\mathrm{CO}_{2}$ effects on thermal tolerance}

During exposure to increased $\mathrm{CO}_{2}$ concentrations $(710 \mathrm{ppm}$ and $3000 \mathrm{ppm}$ ) the $\mathrm{P}_{\mathrm{e}} \mathrm{O}_{2}$ of Hyas araneus displayed various decline phases between $0^{\circ} \mathrm{C}$ and $25^{\circ} \mathrm{C}$ resembling those under normocapnic conditions (Fig. 3). The same was true for 
the pattern of heart rate. However, levels of heart rate and $\mathrm{P}_{\mathrm{e}} \mathrm{O}_{2}$ differed between $\mathrm{CO}_{2}$ levels. Heart rate resulted lower between 10 and $0^{\circ} \mathrm{C}$ under $3000 \mathrm{ppm}$ than under $710 \mathrm{ppm}$ or normocapnia. This observation together with a trend for $\mathrm{P}_{\mathrm{e}} \mathrm{O}_{2}$ to be lower under high $\mathrm{CO}_{2}$ levels indicate a reduction in functional capacity of oxygen supply in $\mathrm{CO}_{2}$ exposed specimens in the cold.

Above $10^{\circ} \mathrm{C}, \mathrm{CO}_{2}$ concentration influenced the temperature dependent rise in heart rate, which resulted steeper with higher $\mathrm{CO}_{2}$ levels. The increase in heart rate under $3000 \mathrm{ppm}$ $\mathrm{CO}_{2}$ was larger than under $710 \mathrm{ppm}$ or under normocapnia (Fig. 2). The stronger thermal stimulation of heart rate under increasing $\mathrm{CO}_{2}$ levels may reflect a response to lower oxygen tensions and/or a chemosensory response. It may also reflect a stronger increase in metabolic rate. Exposure to acidification likely results in enhanced ventilation and a parallel rise in heart rate, which supports $\mathrm{CO}_{2}$ release and thus the alleviation of $\mathrm{CO}_{2}$ induced $\mathrm{pH}$ disturbances (cf. Pörtner et al., 2005).

Starting from a putative $T_{C}$ above $25^{\circ} \mathrm{C}$ for Hyas araneus under normocapnic conditions $\mathrm{CO}_{2}$ clearly induces a reduction in upper critical temperature to $23.5^{\circ} \mathrm{C}$ under $710 \mathrm{ppm}$ and to $21.1^{\circ} \mathrm{C}$ at $3000 \mathrm{ppm}$ (Fig. 3). These results confirm those obtained earlier in Cancer pagurus by Metzger et al. (2007), where measurements of $\mathrm{PaO}_{2}$ demonstrated a downward shift of critical temperature from $20.5^{\circ} \mathrm{C}$ (normocapnia) to $15.5^{\circ} \mathrm{C}$ under $1 \% \mathrm{CO}_{2}\left(=10000 \mathrm{ppm} \mathrm{CO} \mathrm{CO}_{2}\right)$. All of these findings support the hypothesis that with higher $\mathrm{CO}_{2}$ concentrations and a stronger heat induced stimulation of heart rate the upper critical temperature falls, as a result of synergistic effects of temperature and $\mathrm{CO}_{2}$. In contrast to observations in the cold it may also involve a $\mathrm{CO}_{2}$ induced stimulation of metabolic costs in the warmth.

The additional decrement in heart rate at low temperatures may possibly involve an accumulation and effect of adenosine under $\mathrm{CO}_{2}$ exposure. Adenosine was found to accumulate under elevated $\mathrm{CO}_{2}$ levels and depress ventilation rate in Sipunculus nudus (Reipschläger et al., 1997). The role of $\mathrm{pH}$ in this effect is not clear (Pörtner, 2008). In crustaceans, adenosine also depresses spontaneous activity and the responsiveness of interneurons to electrical and chemical stimuli in the brain (Derby et al., 1987) and elicits bradycardia (Brevard et al., 2003). In contrast, adenosine can display a stimulatory effect on heart rate, haemolymph flow and scaphognathite frequency (Maurer et al., 2008; Stegen and Grieshaber, 2001). This apparent discrepancy resembles the contrasting $\mathrm{CO}_{2}$ effects at low and at high temperatures. A stimulatory effect might in fact be involved in the increase in heart rate with rising $\mathrm{CO}_{2}$ concentrations in the warmth (Fig. 4). Further experiments are required to test these hypotheses.

Stillmann and Somero (1996) identified upper thermal limits in heart rates of the high intertidal crab Petrolisthes cinctipes and the low intertidal crab Petrolisthes eriomerus, which correlated with the natural habitat temperature. Heart rate measurements of Petrolisthes species identified a critical temperature which in the light of our present data and those by Frederich and Pörtner (2000) may indicate a shift from aerobic to anaerobic metabolism. The low intertidal crab Petrolisthes eriomerus displayed a narrower thermal tolerance window and a lower $T_{c}$ of $26.6^{\circ} \mathrm{C}$ with some accumulation of L-lactate at $25^{\circ} \mathrm{C}$ in comparison to the high intertidal crab Petrolisthes cinctipes $\left(T_{c}=31.5^{\circ} \mathrm{C}\right)$ (Stillmann and Somero, 1996). The example of low and high intertidal Petrolisthes species illustrates the specialization of marine species on limited thermal ranges and the ability to live near their thermal limits. For eurythermal Hyas araneus we suggest, that the thermal tolerance window enables the large scale biogeographical distribution of the species. Under normocapnia, the response of Hyas araneus from Helgoland resembles the one of the high intertidal species $P$. cinctipes. In contrast, Hyas araneus under elevated $\mathrm{CO}_{2}$ showed a response similar to $P$. eriomerus, which is a low intertidal species and does not possess such a wide thermal tolerance range. $\mathrm{A} \mathrm{CO}_{2}$ induced narrowing of the thermal tolerance will therefore most likely restrict the geographical distribution of a species. Hyas araneus from Helgoland would already exploit its upper pejus range during present summers (temperature maxima about $20^{\circ} \mathrm{C}$; Wiltshire and Manly, 2004), however without reaching the upper $T_{c}$. The situation may change under elevated $\mathrm{CO}_{2}$ concentrations of $3000 \mathrm{ppm}$ (scenario 2300), where the critical temperature of Hyas araneus was determined at $21.1^{\circ} \mathrm{C}$, which would imply an increase in heat stress during extreme summers and elevated mortality rates.

A schematic model of heart rate changes in Hyas araneus illustrates how the thermal tolerance window is narrowed under the influence of $\mathrm{CO}_{2}$ (Fig. 4). The $\mathrm{CO}_{2}$ induced rise in $Q_{10}$ values in the exponential phases of heart rate may be involved in eliciting the narrowing of thermal windows, in similar was as the $Q_{10}$ enhancement of metabolic rate as recently seen in the lugworm Arenicola marina (Wittmann et al., 2008). In the lugworm model the thermal tolerance window is influenced by seasonal acclimatization to temperature resulting in a narrower window during winter, associated with lower metabolic rates and higher $Q_{10}$ values than in summer (Wittmann et al., 2008).

We can conclude that $\mathrm{CO}_{2}$ induced ocean acidification has the potential to cause a narrowing of thermal windows. The present mechanism based projections indicate that specimens from the southernmost population of a species, when permanently exposed to acidification may lose their capability to acclimate to extreme temperatures. In the future, long term exposures which mimic the long term nature of ocean acidification scenarios more closely will have to complement the present experiments. The North Sea around Helgoland already showed a warming trend during the last 40 years of $1.1^{\circ} \mathrm{C}$ to a mean temperature of $18^{\circ} \mathrm{C}$ and with maximum temperatures of about $20^{\circ} \mathrm{C}$ (Wilthire and Manly, 2004). Personal observations indicate a drastic decrease in 
the abundance of $H$. araneus around Helgoland, which might be linked with summer warming. The present study emphasizes that a further increase in ambient temperature as predicted by the IPCC $(2001,2007)$ combined with increased ocean acidification (Caldeira and Wickett, 2005) may cause animals to reach their physiological limits even sooner. As a consequence Hyas araneus may lose its southern habitats and experience a stronger northward shift of biogeographical boundaries.

Acknowledgements. This work is a contribution to the "European Project on Ocean Acidification" (EPOCA) which received funding from the European Community's Seventh Framework Programme (FP7/2007-2013) under grant agreement $n^{\circ} 211384$. EPOCA is endorsed by the International Programme LOICZ. Supported by the Mar Co POL I research program of Alfred-Wegener-Institute and the BIOACID program of the Federal Ministry of Research, Germany. We would like to thank Timo Hirse and Katherina Schoo for excellent technical assistance.

Edited by: S. Pantoja

\section{References}

Ahsanullah, M. and Newell, R. C.: Factors affecting the heart rate of the shore crab Carcinus maenas (L.), Comp. Biochem. Physiol., 39A, 277-287, 1971.

Bernárdez, C., González-Gurriarán, E., García-Calvo, B., Corgos, A., and Freire, J.: Movements of juvenile and adult spider crab (Maja squinado) in the Ria da Coruna (N-W Spain), Aquatic telemetry: advances and applications, Proceedings of the Fifth Conference on Fish Telemetry held in Europe, Ustica, Italy, 913 June 2003, Rome, FAO/COISPA, 295 pp., 2005.

Bock, C., Frederich, M., Wittig, R.-M., and Pörtner, H. O.: Simultaneous observations of haemolymph flow and ventilation in marine spider crabs at different temperatures: a flow weighted MRI study, Magn. Reson. Imaging, 19, 1113-1124, 2001.

Brevard, M. E., Duong, T. Q., King, J. A., and Ferris, C. F.: Changes in MRI signal intensity during hypercapnic challenge under conscious and anesthetized conditions, Magn. Reson. Imaging, 21, 995-1001, 2003.

Caldeira, K. and Wickett, M. E.: Ocean model predictions of chemistry changes from carbon dioxide emissions to the atmosphere and ocean, J. Geophys. Res., 110, C09S04, doi:10.1029/2004JC002671, 2005.

Cameron, J. N.: Effects of Hypercapnia on Blood Acid-Base Status, $\mathrm{NaCl}$ Fluxes, and Trans-Gill Potential in Freshwater Blue crabs, Callinectes sapidus, J. Comp. Physiol., 123, 137-141, 1978.

Cameron, J. N.: Compensation of hypercapnic acidosis in the aquatic blue crab, Callinectes sapidus: the predominance of external sea water over carapace carbonate as the proton sink, J. Exp. Biol., 114, 197-206, 1985.

Cameron, J. N. and Iwama, G. K.: Compensation of progressive hypercapnia in channel catfish and blue crabs, J. Exp. Biol., 133, 183-197, 1987.

Christiansen, M. E. (Ed.): Crustacea Decapoda Brachyura, in: Marine Invertebrates of Scandinavia, No. 2, Universitetsforlaget, Oslo, 1969.
Cuculescu, M., Hyde, D., amd Bowler, K.: Thermal tolerance of two species of marine crab, Cancer pagurus and Carcinus maenas, J. Therm. Biol., 23, 107-110, 1998.

DeFur, P. L. and Mangum, C. P.: The effects of environmental variables on the heart rate of invertebrates, Comp. Biochem. Physiol., 62A, 283-294, 1979.

Derby, C. D., Ache, B. W., and Carr, W. E. S.: Purinergic modulation in the brain of the spiny lobster, Brain Research, 421, 57-64, 1987.

Frederich, M. and Pörtner, H. O.: Oxygen limitation of thermal tolerance defined by cardiac and ventilatory performance in spider crab, Maja squinado, Am. J. Physiol. Regulatory Integrative Comp. Physiol., 279, R1531-R1538, 2000.

Frederich, M., Sartoris, F. J., Arntz, W. E., and Pörtner, H. O.: Haemolymph $\mathrm{Mg}^{2+}$ regulation in decapod crustaceans: Physiological correlates and ecological consequences in polar areas, J. Exp. Biol., 203, 1383-1393, 2000.

IPCC: Climate Change 2001: Third Assessment Report of the Intergovernmental Panel on Climate Change, Campridge University Press, Campridge, 2001.

IPCC: Climate Change 2007, Fourth Assessment Report of the Intergovernmental Panel on Climate Change, Cambridge University Press, Cambridge, 2007.

Lannig, G., Cherkasov, A. S., Pörtner, H. O., Bock, C., and Sokolovy, I. M.: Cadmium-dependent oxygen limitation affects temperature tolerance in eastern oysters (Crassostrea virginica Gmelin), Am. J. Physiol. Regul. Integr. Comp. Physiol., 294, R1338-R2346, 2008.

Maurer, G., Wilkens, J. L., and Grieshaber, M. K.: Modulatory effects of adenosine and adenine nucleotides on different heart preparations of the American lobster, Homarus americanus, J. Exp. Biol., 211, 661-670, 2008.

Melzner, F., Bock, C., and Pörtner, H. O.: Critical temperatures in the cephalopod Sepia officinalis investgated using in vivo ${ }^{31} \mathrm{P}$ NMR spectroscopy, J. Exp. Biol., 209, 891-906, 2006.

Metzger, R., Sartoris, F. J., Langenbuch, M., and Pörtner, H. O.: Influence of elevated $\mathrm{CO}_{2}$ concetrations on thermal tolerance of the edible crab Cancer pagurus, J. Therm. Biol., 32, 144-151, 2007.

Orr, J. C., Maier-Reimer, E., Mikolajewicz, U., Monfray, P., Sarmiento, J. L., Toggweiler, J. R., Taylor, N. K., Palmer, J., Gruber, N., Sabine, C. L., Le Quéré, C., Key, R. M., and Boutin, J.: Estimates of anthropogenic carbon uptake from four three-dimensional global ocean models, Global Biogeochem. Cy., 15(1), 43-60, 2001.

Pane, E. F. and Barry, J. P.: Extracellular acid-base regulation during short-term hypercapnia is effective in a shallow-water crab, but uneffective in a deep-sea crab, Mar. Ecol. Prog. Ser., 334, 1-9, 2007.

Pohlmann, T.: Predicting the thermocline in a circulation model of the North Sea - Part I: model description, calibration and verification, Cont. Shelf Res., 16(7), 131-146, 1996.

Pörtner, H. O.: Climate variations and the physiological basis of temperature dependent biogeography: systemic to molecular hierarchies of thermal tolerance in animals, Comp. Biochem. Phys. A, 132, 739-761, 2002.

Pörtner, H. O., Langenbuch, M., and Michaelidis, B.: Synergistic effects of temperature extremes, hypoxia, and increases in $\mathrm{CO}_{2}$ on marine animals: From Earth history to global change, J. Geo- 
phys. Res., 110, C09S10, doi:10.1029/2004JC002561, 2005.

Pörtner, H. O.: Climate-dependent evolution of Antarctic ectotherms: an integrative anaysis, Deep-Sea Res. II, 53, 10711104, 2006

Pörtner, H. O. and Knust, R.: Climate Change Affects Marine Fishes Through the Oxygen Limitation of Thermal Tolerance, Science, 315, 95-97, doi:10.1126/science.1135471, 2007.

Pörtner, H. O.: Ecosystem effects of ocean acidification in times of ocean warming: a physiologist's view, Mar. Ecol. Prog. Ser., 373, 203-217, 2008.

Pörtner, H. O. and Farrell, A. P.: Physiology and Climate Change, Science, 322, 690-692, doi:10.1126/science.1163156, 2008.

Reipschläger, A., Nilsson, G. E., and Pörtner, H. O.: A role for adenosine in metabolic depression in the marine invertebrate Sipunculus nudus, Am. J. Physiol.-Reg. I., 272, R350-R356, 1997.

Spicer, J. I., Raffo, A., and Widdicombe, S.: Influence of $\mathrm{CO}_{2}$ related seawater acidification on extracellular acid-base balance in the velvet swimming crab Necora puber, Mar. Biol., 151, 1117-1125, 2007.

Stegen, E. and Grieshaber, M. K.: Adenosine increases ventilation rate, cardiac performance and haemolymph velocity in the American lobster Homarus americanus, J. Exp. Biol., 204, 947-957, 2001.

Stillman, J. H. and Somero, G. N.: Adaption to temperature stress and aerial exposure in congeneric species of intertidal porcelain crabs (genus Petrolisthes): Correlation of physiology, biochemistry and morphology with vertical distribution, J. Exp. Biol., 199, 1845-1855, 1996.
Svendsen, H., Breszczynska-Møller, A., Hagen, J. O., Lefauconnier, B., Tverberg, V., Gerland, S., Ørbæk, J. B., Bischof, K., Papucci, C., Zajaczkowski, M., Azzolini, R., Bruland, O., Wiencke, C., Winther, J.-G., and Dallmann, W.; The physical environment of Kongsfjorden-Krossfjorden, an Arctic fjord system in Svalbard, Polar Res., 21(1), 133-166, 2002.

Truchot, J.-P.: Water carbonate alkalinity as a determinant of hemolymph acid-base balance in the shore crab, Carcinus maenas: a study at two different ambient $P \mathrm{CO}_{2}$ and $\mathrm{PO}_{2}$ levels, J. Comp. Physiol. B, 154, 601-606, 1984.

Wickins, J. F.: The effect of hypercapnic sea water on growth and mineralization in penaeid prawns, Aquaculture, 41, 37-48, 1984.

Wiltshire, K. H. and Manly, B. F. J.: The warming trend at Helgoland Roads, North Sea: phytoplankton response, Helgoland Mar. Res., 58, 269-273, 2004.

Wittmann, A. C., Schröer, M., Bock, C., Steeger, H.-U., Paul, R. J., and Pörtner, H.-O.: Indicators of oxygen- and capacity-limited thermal tolerance in the lugworm Arenicola marina, Climate Res., 37, 227-240, 2008.

Worden, M. K., Clark, C. M., Conaway, M., and Qadri, S. A.: Temperature dependence of cardiac performance in the lobster Homarus americanus, J. Exp. Biol., 209, 1024-1034, 2006.

Zainal, K. A. Y., Taylor, A. C., and Atkinson, R. J. A.: The effect of temperature and hypoxia on the respiratory physiology of the squat lobsters, Munida rugosa and Munida sarsi (Anomura, Galatheidae), Comp. Biochem. Physiol., 101A, 557-567, 1992. 